\title{
The Role of Law in Economic Development: To Develop a Special Economic Zone in Order to Build a National and Regional Economy
}

\author{
Budiman Ginting
}

Department of Law, University of North Sumatra, Medan City, Indonesia

\author{
Rosnidar Sembiring \\ Department of Law, University of North Sumatra, Medan City, Indonesia \\ Mahmul Siregar \\ Department of Law, University of North Sumatra, Medan City, Indonesia \\ Afrita Abduh \\ Department of Law, University of North Sumatra, Medan City, Indonesia
}

\begin{abstract}
Purpose - The purpose of this paper is to provide legal certainty in developing a special economic zone (SEZ) in order to build the national and regional economy. Besides that, an other purpose is to push the Central Government, the Provincial Government, the Regional Goverment, and the Management Institution to complete the infrastucture and also harmonize the policies and regulations regarding the SEZ in Indonesia, especially in Sei Mangkei.

Design/Methodology/Approach - The research method that authors used is the sociological legal research and the normative legal research which approach the economic development in social economic zone in Sei Mangkei, the issues that happened in reality, and they analyze the related regulation in SEZ.

Findings - The result thus obtained shows that legal certainty has not been realized completely which caused undevelopment of SEZ in Sei Mangkei. Besides the legal certainty factor, the unfinished infrastructure also caused the undevelopment, even though according to Act number 39 of 2009 regarding SEZ, an operated SEZ has fulfilled the needs and appropriateness of the infrastructure. In reality, Sei Mangkei SEZ, which has been operational, is not supported by the appropriateness of the infrastructure such as the port, train rail, hazardous waste material management facility, final disposal vessel, and also the issue of electricity and gas.

Practical Implications - This result can help Central Government or Provincial Government in establishing the regulations that can provide the legal certainty in developing the SEZ in Sei Mangkei.

Originality/Value - In addition to increasing the role of law in economic development understanding, this paper can be of legal and economic relevance.
\end{abstract}

Keywords Role of law, special economic zone, economic development

(C) Budiman Ginting, Rosnidar Sembiring, Mahmul Siregar, Afrita Abduh. Published in the Emerald Reach Proceedings Series. Published by Emerald Publishing Limited. This article is published under the Creative Commons Attribution (CC BY 4.0) licence. Anyone may reproduce, distribute, translate and create derivative works of this article (for both commercial and non-commercial purposes), subject to full attribution to the original publication and authors. The full terms of this licence may be seen at http://creativecommons.org/licences/by/4.0/legalcode

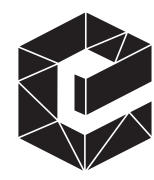

Emerald Reach Proceedings Series Vol. 1 Emerald Publis-214 2516-2853 DOI 10.1108/978-1-78756-793-1-00012 
Proceedings of MICoMS 2017

All papers within this proceedings volume have been peer reviewed by the scientific committee of the Malikussaleh International Conference on Multidisciplinary Studies (MICoMS 2017).

\section{Introduction}

Economic development is the demand of the constitution to achieve the goal of the Republic of Indonesia, which is to improve social welfare for every citizen of Indonesia. Ideally, the development is sponsored by national financial sources, especially from State Budget. But in fact, the State Budget is incapable of covering the financial need of the development. For that, the Indonesian Government try to invite investors, both domestic and foreign, to be a part of national economic development.

The effort to invite investors has been conducted since 1967 by establishing legal certainty in investment with direct investment legal framework, regulated in Act number 1 of 1967 regarding Foreign Investment. A year later, the Government enacted Act number 6 of 1968 regarding Domestic Investment to attract domestic investors to make direct investment in Indonesia. Since then, various facilities/conveniences have been promised by the law of direct investment. But there is some inequality between territories in direct investment which is mostly in Java, more than other territories.

One of the government policies related to this issue is by establishing regional strategic areas, such as Free Port and Free Trade Areas (1970), Bonded Zone (1986), Industrial Zone (1989), Integrated Economic Development Area (KAPET) in 1996, and Special Economic Zone (SEZ) (2009). Those strategic areas are capable of increasing investment in various areas. But the issue of investment such as legal certainty, politic stability, bureaucracy, regional infrastructure sufficiency and qualification are still occurring, causing setback in creating proper investment environment.

In 2009, the government enacted Act number 39 of 2009 regarding SEZ. It was furthermore responded by establishing 11 SEZs, Maloy Batuta Trans Kalimantan SEZ, Sorong SEZ, Morotai SEZ, Bitung SEZ, Palu SEZ, Mandalika SEZ, Tanjung Lesung SEZ, Tanjung Kelayang SEZ, Tanjung Api-Api SEZ, Sei Mangkei SEZ, and Arun Lhokseumawe SEZ.

\section{Explanation}

\subsection{The role of law in economic development}

In improving the competence of the country, legal policy in Indonesia directs the law development to support the realization of continuance economic growth; to regulate issues regarding economy, especially business and industry; and also to create certainty in investment, especially law enforcement and protection law development is implemented with law renewal by still considering the plurality of legal system and the influence of globalization as the effort to increase the legal certainty and protection of human rights, with the environment which constantly changes and to answer the new issue brought by the changes (Sulistiyono, 2007).

The role of law which is very important in economic life is regarding the ability to influence the certainty level between human in society. As stated by H.W. Robinson (Hadisumarto, 1993) modern economy sees that the expectations of individuals are the determinants of economic actions and because of that they are crucial in deciding the equilibrium of economy and the stability of the achieved equilibrium. The businessman, the sponsor, the land owner, the workers, and the consumers conducting the predicted activity will provide the maximum result. In the vibe of modern complex world, some of the result can be predicted. 
Nyhart (1964) stated the six concepts in law that have influence in economic development. The six concepts are: predictability, procedural ability, codification of the goal of legislation that can be seen as one codification of goals and intentions of a country, the balancing factor, and accommodation. The last factor, the sixth, the definition and the clarification of status. Besides the function of law as to provide predictability, it can be added that the function of law is also to provide firmness regarding the status of individuals and the objects in society.

Similar issue is explained by Burgs (Theberge, 1980) saying that there are at least two types of quality of law which must be fulfilled for economic system to be functioned: stability and predictability. But between those two qualities, there is also a justice factor such as keeping similar treatment with government behavior pattern standard which is necessary to keep the market mechanism and prevent a too much bureaucracy.

All this time, the main weakness in law faced by businessman is the legal uncertainty. Legal certainty is indeed necessary to calculate and anticipate the risk, for a country, legal certainty is even one of the most important factors in supporting the endurance of economy in a country (Himawan, 1998). In order make law adjustable for this situation, the government is responsible to make the law with sufficient dignity in responding to any demand necessary for economic development. Besides legal certainty, to handle the increasing need of efficiency, legal institutions must be able to play its crucial part or role in adjusting the ideas and condition which constantly develops (Chatamarrasjid, 2003).

The success of SEZ in improving national and regional economy will be decided by the existence of proper law in providing legal certainty and efficiency in the management.

\subsection{Concept and regulation of SEZ in Indonesia}

The term "Special Economic Zone" has a wide meaning since it can be used to explain many types of commercial zone. The industries such as Maquiladora, Mexico, and Shenzhen are SEZ, even though they have difference in the structure and measurement. This term is commonly known as modern iteration from free commercial zone, which was first established in 1959 in Shannon, Ireland (Damuri, 2015).

According to World Bank, SEZ in any form is at least built with limited and separated area of customs, under one regulating entity, where it can be used by them located in the area (Akinci and Crittle, 2008). In other words, SEZ is a zone where the government expects to increase the economic growth through export and investment raise by providing many competitive conveniences in the zone.

According to Act number 39 of 2009 regarding Special Economic Zone, SEZ is defined as a zone with certain boundary in Indonesia, established to implement the function of economy and to achieve certain facility. The operational definition brings the incentive aspect regarding certain facility provided by the government to investor in SEZ. According to Article 2 Act of Special Economic Zone, SEZ was developed with the preparation of zone having geo-economy and geo-strategy superiority and functioned to accommodate the activities of industry, export, import, and other activities having high economic values and high international competence.

In Government Regulation number 2 of 2011, institutions of SEZ which are National Council, Sectored Council, and Administrator have been explained, where each has the role and position in running its duty. SEZ management is conducted by the Administrator and business institution that manage and also supervise regarding the physical building process of the SEZ in one place which has the consent of the President.

The promised incentive in SEZ is more than the incentive given to other strategic economic zone as seen in Table 1.

\section{The Role of Law in Economic Development}

211 


\section{Proceedings of MICoMS 2017}

\section{2}

\section{Table 1.}

Comparison of Investment Facility in Strategic Zones in Indonesia

Facility
1. Facility of Institution tax income
a. Investment allowance
b. Quickened amortization
c. Dividend tax
d. Longer disadvantage compensation
e. Holiday tax
2. Facility of tax income exemption article 22 import
3. Value added and luxury good tax facility
a. Uncollected value added tax of import
b. Uncollected value added tax on domestic purchase
c. Exemption on value added tax/luxury good tax
d. Referral of the uncollected to the user of the facilities
e. Giving back the value added tax to individual of international
passport holder
4. Customs and excise tax facility
a. Suspension of custom
b. Exemption of custom
c. Exemption of excise
d. Suspension of custom

Source: National Council of SEZ (2015).

${ }^{\mathrm{a}}$ Given to the businessman in bonded zone (PDKB) in the territory of KAPET.

${ }^{\mathrm{b}}$ Given to the businessman in bonded zone (PKB)/PDKB in the territory of KAPET.

${ }^{\mathrm{c}}$ Given to PKB/PKB including PDKB in the territory of KAPET.

${ }^{\mathrm{d}}$ Given to industry businessman in certain service in KAPET.

To guarantee legal certainty in implementing SEZ, the government of Indonesia has issued legislations to respond Act number 39 of 2009 regarding SEZ such as the following:

(1) In the aspect of institution: Presidential Decree number 8 of 2010 regarding National Council of Sectored Economic Zone, Presidential Regulation Number 33 of 2010 regarding national council and SEZ council, Presidential Regulation number 124 of 2012 regarding Alteration on Presidential regulation number 33 of 2010 regarding National Council and SEZ Council, Presidential regulation number 150 of 2014 regarding second Alteration on Presidential Regulation number 33 of 2010 of National Council and SEZ Council, and Presidential Decree of Province SEZ according to the established SEZ.

(2) In implementing SEZ: Government regulation number 2 of 2011 regarding implementation of SEZ, Government Regulation number 100 of Alteration on Government Regulation number 2 of 2011 regarding SEZ, Regulation of city government number 7 of 2011 regarding the guidance of proposal in forming SEZ and Regulation of city government number 8 regarding the guidance of evaluation in forming SEZ.

(3) In facility aspect of SEZ: Government Regulation number 96 of 2015 regarding facility and convenience in SEZ, Implementing Regulation number 96 of 2015 issued by certain ministry consisted of: fiscal (tax and custom); labor; land; immigration; goods traffic; and license convenience, and Financial Ministry Regulation number 104/PMK.010/2016 regarding tax, customs, and excise treatment in SEZ. 


\subsection{Legal certainty in SEZ development}

Legal certainty is a crucial factor to attract the investors to invest in SEZ. With legal certainty, investor can predict the investment by considering the conditions guaranteed in the existed legal norms. Based on the development of Sei Mangkei SEZ, it can be concluded that legal certainty has not been realized completely. In the explanation of Article 12 (1) Act number 39 of 2009 regarding SEZ, "must be ready to operate" means the fulfilment of infrastructure, human resource, and administration control tool. Sei Mangkei SEZ has been operated since 27 January 2015. But the supporting infrastructure of investment in and Law in Economic Development outside the sector has not completely built and was unable to function properly by the tenant.

Some of the issues regarding Sei Mangkei SEZ supporting infrastructure are as follows:

(1) The unfinished train rail from Bandar Tinggi Station to Kuala Tanjung Port of of $\pm 21.5 \mathrm{~km}$.

(2) The unfinished building of Global Hub Kuala Tanjung Port.

(3) The non-availability of accommodation to hold hazardous waste material.

(4) The non-availability of final disposal vessel produced by the industries of SEZ.

(5) The relatively expensive price of gas and electricity in Sei Mangkei SEZ.

In order to accelerate the investment in SEZ, which can support national economic development, Government regulation number 96 of 2015 is issued regarding the Facility and Convenience in the SEZ (Government Regulation of Facility and Convenience in SEZ). But this regulation is not completely operated yet.

PTPN 3 Medan as the developer of Sei Mangkei SEZ complained regarding the tax convenience which was actually a part regulated in the Government regulation regarding Facility and Convenience in SEZ, but in reality, the change of land status of Sei Mangkei SEZ from cultivation right to management right which has been put in the management right certificate number 1 of 2014, caused regional tax raise. The developer of Sei Mangkei SEZ finds that it is necessary to provide certain incentive from Regional government such as: reduction/exemption of property tax and duties on the rights and buildings to attract investors in the form of regional regulation for Sei Mangkei SEZ.

\section{Conclusion and suggestion}

Law plays an important role in creating certainty and predictability in investment. Without the legal certainty assurance, the economy development is uneasy to be conducted, since the support is hard to get.

Development and management of SEZ has not guaranteed complete and whole legal certainty. The experience in developing Sei Mangkei SEZ shows that legal certainty has not been realized completely. The issue of legal certainty also has not been completely realized regarding the facilities and investment incentive. The promised incentive by law has not been realized and the handling is complicated and bureaucratic.

According to the above-mentioned conditions, it is suggested that the Central Government, the Provincial Government, the Regional Government, and the Management Institution, according to each authority, have to complete the unfinished infrastructure. Besides that, more systematic effort must be done to harmonize the policies regarding the SEZ management. 


\section{Proceedings of References}

MICoMS 2017 Akinci, G. \& Crittle, J. (2008). Special Economic Zones: Performance, Lessons Learned, and Implications for Zone Development, Foreign Investment Advisory Service (FIAS) Occasional Paper. World Bank. Washington, D.C. pp. 9.

Chatamarrasjid, A. (2003). Pendekatan Ekonomi Terhadap Hukum. Professor Inauguration Speech University of Yarsi, 4 October 2003, UI-Press, Jakarta.

Damuri, R.Y. (2015). Kawasan Ekonomi Khusus dan Strategis di Indonesia: Tinjauan atas Peluang dan Permasalahan, Centre for Strategic and International Studies, Jakarta

Hadisumarto. (1993). Sambutan Seminar Sehari Implikasi Reformasi Hukum Bisnis Terhadap Perekonomian Indonesia, organized by Magister Management Program of University of Indonesia. 8 Desember 1993. pp. 2.

Himawan, C. (1998). “Mercusuar Hukum Bagi Pelaku Ekonomi”, Kompas, 21 April 1998, pp. 9.

Nylhart, J.D. (1964). Rule of Law and Economic Development, Massachussetts Institute of Technology, Cambridge.

Sulistiyono, A. (2007). Pembangunan Hukum Ekonomi untuk Mendukung Pencapaian Visi Indonesia 2030. Professor Inauguration Speech in Economic Law. University of Sebelas Maret. Surakarta. 17 November 2007. pp. 12.

Theberge, L.J. (1980). "Law and Economic Development". Journal of International Law and Policy, Vol. 9, pp. 231-238.

\section{Corresponding author}

Ginting can be contacted at budiman_ginting59@yahoo.com 